\title{
Rho GTPase-Activating Protein 45
}

National Cancer Institute

\section{Source}

National Cancer Institute. Rho GTPase-Activating Protein 45. NCI Thesaurus. Code C157546.

Rho GT Pase-activating protein $45(1136 \mathrm{aa}, \sim 125 \mathrm{kDa})$ is encoded by the human ARH GAP45 gene. This protein is involved in the activation of Rho family GT Pases. 